\title{
Psychosocial Factors Involved in Absenteeism-A Qualitative Analysis in a Brazilian Context
}

\author{
Alessandro Vinicius de Paula1,2, Ximena Christina de Carvalho Oliveira3, \\ Ana Alice Vilas Boas² ${ }^{2}$ Júlia de Moura Martins Guimarães ${ }^{1,4}$ \\ ${ }^{1}$ Federal Technology University of Paraná-Francisco Beltrão (UTFPR-FB), Francisco Beltrão, Brazil \\ ${ }^{2}$ Federal University of Lavras (PPGA-UFLA), Lavras, Brazil \\ ${ }^{3}$ Lavras, Brazil \\ ${ }^{4}$ Federal Institute of Education, Science and Technology of South of Minas Gerais (IFSULDEMINAS), \\ Pouso Alegre, Brazil \\ Email: avpaula@yahoo.com.br
}

Received 17 April 2014; revised 12 May 2014; accepted 29 May 2014

Copyright (C) 2014 by authors and Scientific Research Publishing Inc.

This work is licensed under the Creative Commons Attribution International License (CC BY). http://creativecommons.org/licenses/by/4.0/

(c) (i) Open Access

\section{Abstract}

Work is a fundamental activity for human beings not only because it provides the benefit of a wage but also because it allows the subject to draw primitive anxieties that are evoked only in the frame of human-work relations. In Brazilian context, removed workers are often victims of prejudice beyond the organization space, triggering feelings of weakness and uselessness. The absence from work may also jeopardize both physical and mental health. Thus, this study aims to understand the psychosocial factors (social support, affect, coping skills and perception of future and health status) involved in absenteeism and the process of withdrawing work and its consequences on people's lives. A qualitative approach was chosen for gathering and analyzing data. Four workers from different professional categories participated in this qualitative study. It was observed that stop working brought serious implications for the lives of investigated subjects, who reported feelings of estrangement, fear, emptiness, depression, helplessness and dependence. The most frequent difficulties in relation to absenteeism refer to the part of the tie break of social and financial issues. The main strategy for dealing with problems arising from job withdraws was to seek social support from friends and family. Regarding plans and the prospective, they experienced a critical period (immobilization), requiring a process of (re)adapting to the new situation ahead. Given the above, it is noteworthy to understand that the consequences of absenteeism or temporary withdrawing of labor become a necessary measure to preserve physical and mental health; a task open to interventions of work and organizational psychology. 


\section{Keywords}

\section{Absence from Work, Psychosocial Factors, Absenteeism, Work, Qualitative Analysis}

\section{Introduction}

Work occupies a central place in the life of human beings. The man "is made" in connection with his work and the work is a human activity for excellence, which holds a mediation between man (society) and nature. Work is a structuring category in human life, as far as man interacts with the environment, through his work the man appropriates nature and transforms himself and his world. Such transformations allow him to participate and offer meaning to his own existence through time, and it takes place historically and socially (Jacques, 1997).

In the current configuration of sociability, the existence of every human being is permeated by work, and work is the activity that regulates the various schedules and routines of everyday life-including leisure and rest. Work also defines interpersonal relationships, forms of inclusion, participation and social recognition; therefore, it is a way to build the identity of human beings (Jacques, 1997; Morin, Tonelli, \& Pliopas, 2007). It is also noticed when we see that, generally, one of the most common questions we ask a person whom we just met is: "Where do you work?" or "What do you do"?

When studying the "work" category, it is important to understand the concepts that individuals have about their own professional activity. In fact, work is defined in many ways and it takes different meanings for human beings. Thus, it is important to identify the teleological character of labor activity. In other words, the notion that man works for a purpose is established even before the completion of the work itself. Apart from the objective and materials features of work, it plays also an important subjective role and a psychological function. Work is fundamental in the constitution of humans beings and their network of meanings, involving processes of identification and social recognition, affective and cognitive mobilization, subjective strengthening of the individual and the working group to which he belongs (Jacques, 1997; Morin, Tonelli, \& Pliopas, 2007; Vilas Boas \& Morin, 2014). Unlike the activity of some animals, such as the bee that produces honey mainly due to a biological characteristic. Lukács (1978) explains this issue by stating that:

The essence of work goes precisely beyond the determination of living beings in the biological competition with the surrounding world. The timing essentially separatory is constituted not by manufacturing products, but the role of consciousness, [...], says Marx, it is a result that early in the process there was "already in the representation of work", that is, in a ideally form (Lukács, 1978: p. 4).

According to Mendes-Silva and Hashimoto (2003), work is essential for man not only in the real plan, because it carries a salary that allows the individual to survive or a compensation that enables him to establish future projects. It is also essential to ensure this subject draw primitive anxieties that are only mentioned in the framework of man-labor relations. Or, work is also important because, through it, the subject enables his affections and enhances his creative and productive capacities, from which you can obtain the recognition of the other, something essential to the construction of their own identity.

Due to the importance that the work has in the construction of human beings' identity, the individual is able to perceive himself as a "whole" while observing the possibility of self-transformation through his work. However, in some specific work contexts, this process of identity construction may not occur. There are many workers who are removed from their occupations due to harmful factors related to work or health problems. Even those who leave their occupation, because it is time to retire may experience a similar process. Therefore, to understand the consequences of this process and the ambiguity of leaving a job becomes a necessary measure to try to preserve the physical and mental health of the subject.

It is important to notice that some questions are fundamental to (re)consider in the relation between workers and their work, especially in the context of withdrawal-temporary or one-step process to get to retirement. How, a person, which is not able to exercise their labor activity, feels? What is her perception about her new role in the society? How to (re)establish family and social relationships? How the worker experiences this condition of inactive? In view of the above, the present study aims to understand the psychosocial factors (interaction between psychological and social factors, for example, social support, affect, coping skills and perception of future 
and health status), which are involved in the withdrawal from work and its consequences in the lives of people who are experiencing this situation.

This study aims to discuss the psychosocial factors involved in the process of removal of work, emphasizing the experiences of workers removed from work. This approach is necessary since most studies on removal/ return to work deal primarily with aspects related to the programs of (re)integration of workers into their own work place-addressing the interventions required to facilitate reintroduction of this work and related topics (Franche, Baril, Shaw, Nicholas, \& Loisel, 2005; Franche, Cullen, Clarke, Irvin, Sinclair, \& Frank, 2005; Shaw, Hong, Pransky, \& Loisel, 2008; Tompa, Oliveira, Dolinschi, \& Irvin, 2008; Hepburn, Franche, \& Francis, 2010).

Note that, this paper presents an excerpt of a broader research project that aims to understand the implications of labor removal for the individual and his family, as well as the company's position in face of such situation and the public policies aiming the minimization of the suffering of workers involved in this process.

\section{Brief Considerations on Absenteeism}

Work can be a source of pleasure or just a way to survive. Not all workers had the opportunity to practice the profession they would like or even to have a satisfactory job. Some might not spent much time or money in the process of formal education - for many, the choice of the job activity is determined for being practical, quick and profitable. In any situation, the meaning of work must be analyzed for these people, since, as pointed, Vilas Boas and Morin (2013a, 2013b) work is an important source of meaning in the lives of human beings.

For Wrzesniewski, Dutton and Debebe (2003), a meaningful work refers to the understanding that employees have about what they do at work and the importance they give to their own work. On the other hand, Pratt and Ashforth (2003) or Vilas Boas and Morin (2013a, 2013b) argued that there is a difference between the meaning of work and the meaning at work. Meaning of work refers to the roles and the tasks an individual is performing in his job while the meaning at work refers to the relations and the conditions the individual has while performing his duties at work. In such context, we may see clearly that the feelings towards absenteeism can be influenced by the meaning of work and the meaning at work.

Indeed, in her surveys in four organizations, Morin (2008) found that workers were making a difference between work meaningfulness and work environment meaningfulness, the first being associated with the work itself and its characteristics, and the second, with the relations the person has with his/her colleagues and the management. Once again, work relations will change when an employee is removed from his job because of some illness, for instance.

Some people lose some important references in their lives when they have to withdraw from their jobs. Individuals who are professionally active, but suddenly, due to factors such as an unexpected job accident or some health problems, have to leave that environment where they built much of their histories, face a huge impact on their lives. This work environment is always taken as a form of survival. In this context, the removal from labor activity may represent a break within the formal professional role, rather than an experience of deserved rest. It can also be experienced as a threatening or unsafe situation that may lead the individual to a psychological imbalance.

Being away from work means much more than being unable to exercise professional commitments. Workers removed from work are usually victims of bias that exceeds organizational sphere and invades social and private spheres (Mendes-Silva \& Hashimoto, 2003; Olivier, Perez, \& Behr, 2011). According to Antunes (1999), it is because work permeates all spheres of life, which means that the involvement within the working life undermine, to some extent, the achievements of "out of work" spheres.

In Brazil, there is a bad social representation for individuals who leave their jobs, and they are normally labeled as invalid, sick, lame, leaning, and so on. Within these stereotypes, all that is related to their psychological structure becomes extremely fragile and susceptible. As pointed out by Mendes-Silva and Hashimoto (2003), the individual feels immobilized, weakened and in many moments, he disqualifies himself, which prevents the development of plans and the establishment of personal and professional projects.

Besides these situations of prejudice, workers whose removal occurs due to some health problem often complain about the attitude of neglecting and inattention of the company where they worked in monitoring the progress of their cases. This neglect leaves workers without knowing exactly what are their labor rights, their actual health condition, and their chances of recovery. The removal of work is reflected in life change, and that 
for most people who experience this context, this new condition is pervaded by a mixture of feelings of disgust, anger, fear and insecurity, especially by not knowing what to do and how long this condition will remain. Within the end of professional life, many other significant factors for social life eventually become extinct too, as recognition in the society, reference in the profession, professional commitments and schedules, and the feeling of "being useful". But, there is also a more serious consequence: the dispelled employees, often experience the high cost of a prejudice inflicted by his own family. In this case, it is not difficult to understand that this situation leads to a condition of helplessness (Mendes-Silva \& Hashimoto, 2003).

To finalize this picture, researches have shown that the greater the involvement and satisfaction with work, the harder it becomes for the employee withdraw his job. The role and position played cannot determine involvement and satisfaction, but the higher the status generated by the post, harder it will be to leave it. Therefore, it is essential to analyze what the position or the function means for that person who plays such occupation (Morin, Tonelli, \& Pliopas, 2007). As we can see, the absence from work is reflected in a change of life, and most people who experience this situation reports a mixture of feelings of disgust, anger, fear and insecurity, especially for not knowing what to do and how long this condition will remain.

In general, in the Brazilian context, these people are directed to the Social Security System and subjected to lengthy processes of examination, investigation and etc. Creating suffering and evoking questions like, "When can I return to work?”; “Would I be back?” and "Would I be accepted at my old job?” These expectations will create conflicts, causing anxiety and fear, in fact, a suffering that only ends when the employee reaches the retiring age (disability) or he can return to work. Within the end of the working life, many other factors eventually become extinct such as a significant part of social life, recognition of the company, reference in the profession, appointments, schedules, and the feeling of "being useful".

The main function of withdrawing from work should be to provide the opportunity for treatment. However, this kind of interruption generates multiple and different effects on the worker's life, which encompasses aspects of his personality intertwined with the social context in which he lives. The work plays a central role in the constitution of the identity therefore; the difficulties experienced in its scope tend to have great weight in psychological aspects. In general, some authors state that the lower the worker's autonomy in the organization, the greater the possibility of that the employee will suffer some mental disorders or some damages on his mental health (Lacaz, 2009).

Besides physical and psychological damage, work absenteeism may also represent material and social losses, as the drop in financial resources and the distance from the group of colleagues, among others, may lead on decreased self-esteem and motivation, and lead to mental illness that is reflected in depressive episodes, anxiety, alcoholism and even suicide (Rodrigues, Ayabe, Lunardelli, \& Canêo, 2005). Regarding the economic issue, it is observed uncertainty about the future, even among those who have some savings. So much so that, for some people in Brazil, it is imperative that even after retirement, they continue with a work activity to complement their income.

Returning to work is also a complex process. In many cases, workers are transferred to positions with little recognition or hierarchically inferior, and sometimes they are seen as "useless". Some colleagues end up moving away and the anxiety of being back, living in another phase of life, beyond the fear of failing to be competent enough as before, end up generating new disease's symptoms, which is likely to aggravate the case, and lead to more harmful consequences. Thus, it may be a never-ending problem, since one is never prepared to face this prejudice.

The absence from work can cause several damages to the subject. Since work is a structuring activity for human life, any change that occurs in this context also interferes in other areas. Jacques (1997) analyzes the relationship between identity and work and its implications for people who are not included in the labor market. He pointed out that:

When a social set is guided by utility values as in the case of contemporary society, the lack of inclusion in this model and/or its organizational and relational forms are representations of suffering, and they impact on quality of life of its population. It is under this focus that the relationship between identity and work becomes dispensable or indispensable as a priority or not on the emphasis of quality of life in a given society. From this perspective, unemployment, retirement and inactivity reveal a subjective dimension and a social repercussion beyond the statistical data and the economic parameters (Jacques, 1997: p. 45).

From this brief review on impacts of working removal for physical and mental treatment, we may say that 
absenteeism bring impacts to the workers' health. Therefore, empirical studies about the effects of professional removal in different areas are welcome in the field of organizational studies.

\section{Methodology}

This research is characterized as a qualitative exploratory research and aims to investigate the psychosocial conditions of work absenteeism (being it permanent or temporary). For Minayo (2004), qualitative methods or approaches are those that allow the incorporation of meanings and intentionality of the subjects in the study. The relationship among human relations and social structures should be considered as historical human constructions. Thus, we adopted a qualitative approach for gathering and analyzing data regarding four workers whom are absent from their jobs, trying to study and redeem their experiences and their psychosocial effects. The reasons for leaving job were retirement for disability (two subjects), time retirement (a man) and absence from work due to a degenerative health problem (one subject). The researchers conducted individual interviews from August to October 2011 for data collection using a semi-structured guide. With the consent of the participants, the conversations were recorded and transcribed, to allow a consistent data analysis.

According to Minayo (2004), the interview is a very common procedure in the fieldwork carried out by human sciences studies for allowing the researchers to obtain a range of information delivered by the statements of social actors. An issue that is relevant for the use of the interview as a technique for scientific research relies in the fact that it allows, through speech, the development of objective and subjective data, such as structural conditions, systems of values, norms and symbols. Regarding the representativeness of a speech — to understand and generalize the findings to a broader context—one should remember that the speech of a subject is largely the speech of many, because it is submitted to a set of common standards among their own peers (Minayo, 2004).

\subsection{Participants}

The initial contact with the participants occurred at the service station of a Municipal Institute of Social Security in a small town in southern Minas Gerais-Brazil-location where the cases of absenteeism are forwarded. Among several cases registered there, only four subjects agreed to participate as volunteers in this study. There was no preference or even a preliminary investigation to know the subjects' profile or the reasons for temporary absenteeism. Among the participants, three are female and one is male. Their ages range from 31 to 57 years old. Regarding education, two have completed elementary school and the other two have a university degree. Regarding marital status, two respondents are married, one is widower and another one is single. On the grounds of absenteeism, we have cases of disability retirement (two subjects), time for job retirement (one subject) and absence from work due to a degenerative health problem (one subject).

\subsection{Procedures for Collecting and Analyzing Data}

In the beginning, some visits were held for two weeks to the Municipal Institute of Social Security, mentioned previously, in order to know the place's dynamics and address the subjects. After this step, all participants underwent to the same procedure of data collection occurred from August to October 2011. Upon providing information and clarification on the research objectives, as well as the guidance on the voluntary nature of participation in the study, the researcher presented the Informed Consent (as per Resolution n. 196 of the National Health Council-Brazil) and demanded the volunteers to sign it. After that, the individuals start answering the interviews according to the availability of each one. The researcher used a roadmap with open questions to conduct the interviews, in order to allow the interviewees to address the various dimensions of their experiences and enrich their narratives with personal opinions and events. Each interview lasts an average 60 minutes.

The analysis method that best fit the research was content analysis (Bardin, 1995), where speeches and observations collected in the fieldwork were analyzed within the scope of this study. It was carried out a broad reading of all material obtained at the end of process of data collection. For conducting such analyzes and creating the analysis categories, we considered the verbal and non-verbal discourse of the participants. As proposed by Bard in (1995), this methodological process causes a breakdown of speech resulting in units or categories called "evocations". In the sequence, the researcher should make a reunification of ideas in accordance with the same categories. Then, the same stretches of dismembered interviews are organized according to "discursive categories" from memories or facts, which refers to spatiality. 
The results forma series of synthetic discourses, which is the discourse of the collective subject that represent similar individuals or groups of individuals, i.e., their own social representations of that group or subgroup on the highlighted issue. This synthetic discourse keeps the idea of group of people regarding that specific theme or subject. Seeking to understand the speech of absent workers, we used the analysis of categories, which was divided into three main phases:

1) Pre-analysis: consist of reading the transcripts of the interviews to establish relations among the ideas and organizing research material according to the initial categories of analysis, in this case, perceptions about the situation of leaving the job and support received from friends and family;

2) Material exploration or codification: selection of the most significant parts of the interviews that possibly will be used in the analysis process, in this study, they refer to the histories that dealt with absenteeism and their personal, social and economic consequences;

3) Treatment, inference and interpretation of results: analysis and segmentation of data in order to create categories aiming to construct a synthesis of convergences and divergences of the messages from the speeches of the participants, and aiming to understand the declared and subjacent content present in the narratives.

The categorization enabled the organization of similar information, allowing the assignment of meaning and interpretation of qualitative discourse.

\section{Results and Discussion}

The information for this paper was collected through interviews with the participants. The dialogues established with these individuals sought to investigate their perceptions about absenteeism, the support received from friends and family, and the reconstruction of life's projects. For illustration and understanding of these issues, some speeches of the participants are written and commented in the following sections.

\subsection{Perceptions about Work and the Meaning of Work}

It was observed that work has a remarkable economic stability function, but does not limit itself to this aspect. Being active, producing, and having an occupation and linkages arising from the work activities make the work necessary to the human life. Therefore, we asked the participants what is work for them and what is the meaning of work. They responded as follows:

"Work is a great scorer in our character. Gives freedom and independence, and you do not have time to get sick emotionally.” (Participant 1)

"The work is rewarding. We are always updated and involved with different people. Work is necessary for man. As a sort of complement to what we live or need to live.” (Participant 3)

"Work is really for distraction. I'm not ambitious. The work is an accomplishment and no obligation. It is a way to accomplish something. I always pass boring situations when I'm in a circle of friends. Here comes the question: What do you do? I reply that I have worked a lot. Then comes another question: Why do you not work anymore? It's like I say, I give a lot of value in what I do and can do, and if people see it, good! Otherwise, whatever. I strive not to be what others want. I do not feel worse because I do not work. Work is not everything! (Participant 4)

\section{Araújo and Sachuk (2007) point at:}

It is increasingly evident that, in contemporary time, the worker is asked to participate, to get involved and engaged with your work and your career. Disregarding the explorer issue of this aspect in this context [the capitalism], this condition may provide new opportunities for fulfillment and pleasure if you are able to present meanings beyond those grounded in economics and whose biggest feature is to allow the human creation in the sense of self-expression (Araújo \& Sachuk, 2007: p. 64).

It is noticed that, although different meanings are assigned, the participants highlighted the benefits that working activities represent. While we understand the work as a complex category, which can be associated with experiences of pleasure and pain, we cannot fail to stress that this activity is the major route of individual growth and social recognition, as pointed by Vilas Boas and Morin (2013a, 2013b). Especially when it comes to an occupation gifted with meaning for the subject. 


\subsection{The Process of Absenteeism}

The main difficulties in relation to the experience of being away from work, identified in the speeches of the participants, refer to the rupture of social bonds, represented mainly by co-workers, and financial issues, generating uncertainty about what is to come. Their perceptions about this situation are exposed as follows:

"In the first month of retirement, the feeling was that I was on vacation. Then came the feeling of emptiness, the friends were moving away naturally. Then came the depression. I was apathetic, discouraged, with feeling of worthlessness and always missing the interaction with my students and colleagues.” (Participant 3 )

"It was a very strange feeling. It seemed that something had gone away from me. I wondered: And now, it's over? How is it? How do I do? The concern about money was huge, I was afraid they could cut too much in my salary.” (Participant 2).

"What I felt the most was the fact that I was independent. I was where I wanted and I did not need to give satisfaction to anyone. I had to readjust to the independency. Today I feel uncomfortable asking my dad for money, because it is not his obligation. With my illness, I cannot work and the public health system does not collaborate. Nowadays, I help out at home when I'm well.” (Participant 4)

We observe the suffering of respondents when they report feelings of emptiness, depression, helplessness, alienation, worry, fear and dependency due to lack of work. According to Bernal (2010), this can be explained because work is considered an activity that allows the emancipation of the subject through work, as well as the slavery at work. This contradiction is present in the concept of work that can make the subject free (allowing satisfaction, providing a feeling of pleasure, meeting psychosocial needs, and offering direction in the exercise of professional activity), but also can make him slave (being in conditions of exploitation, suffering and control in the work).

When speaking about absenteeism, it is important to consider the physical and mental impairment caused by sudden changes, such as the reduction of the financial income and loss of contact with co-workers. Thus, the subject may undergo changes in his self-esteem (decrease) as well as the motivation itself. These factors can cause depression, anxiety, quest for booze and even attempted suicide (Rodrigues et al., 2005).

\subsection{The Perception of Change: Before and Now}

For Mendes-Silva and Hashimoto (2003), there is mobilization and immobilization for the work removal. So, at first, the individuals tend to disqualify themselves and it becomes a determining factor in preventing the development of new plans and the establishment of new personal and professional projects. The increased anxiety and stress related to the fact that they are away from workplace is common too. Such stress could have more bad consequences in the future, as much as some studies have indicated the association between psychosocial factors and the impact of stress in the onset or worsening of certain specific diseases or in the perception of health status (Soderstrom, Dolbier, Leiferman, \& Steinhardt, 2000; Cropley \& Steptoe, 2005; Devins, Bezjak, Mah, Loblaw, \& Gotoweic, 2006; Dolbier, Smith, \& Steinhardt, 2007; Gerber \& Puhse, 2008; Thomas \& Borrayo, 2011).

However, human being is necessarily characterized by a constant pursuit of well-being, he wants to live well. When speaking of plans and prospects, respondents report the transition that occurred in their lives. After passing through a most critical period of immobilization, nowadays they can deal with the fact that they are no longer working, demonstrating they have gone through a process of adaptation to the new situation they have:

"Before, I wanted to be a teacher. Today I want to buy a farm or live in a place far away and quiet. I enjoy the family and being alone. Oddly enough, I do not think about anything else. I have no need to work harder and I'm so happy.” (Participant 1)

"Today my life is stable. I leave it the way it is. Occasionally, I do some errands just for distraction. I have no plans for the future. I'm used to this condition. Today I'm calm. My days now are summarized in doing things that I like. I have no fixed commitments as before neither nuisance of chief or boss." (Participant 2)

“My plans were to perform volunteer work and it is what I do now. That 'desire' of working passed away. My pleasure is reading, and I want to continue doing my volunteer work and solving the house's problems. Today I have no plans for the future unless the self-realization of my daughter. I still have my routine, but now it is different. Before, I did not have time to have lunch, to rest or even to dedicate to myself. Today, I do a bit of everything and I still take care of my vanity.” (Participant 3) 
“I always go through annoying situations when I'm in a circle of friends. So, comes the question: What do you do? I reply that I have worked too much. Then comes another question: Why don't you stop working? It's like I say, I give a lot of value in what I do and can do, and if people see it, it's great! Otherwise, does not matter. I do not strive to be what others want. By not working, I do not feel worse. [...] Today I attend the gym to distract my head a little bit. I go out and take care of the house when I'm feeling well. I'm chasing retirement because I want to do something for my health without relying on my father. I want to grow up, buy a house, establish my own life. The plans are now "living”. Live today! I'm living without dreaming so much. Let us be objective [smiles].” (Participant 4)

Among the strategies for dealing with problems arising from absenteeism, respondents pointed out the support of a few friends and mostly family members as a great ally. It is because, they are the people who are the closest ones, and relatives welcome these workers in this transition by providing material and emotional support. Participants counted on the support received:

"My husband was very supportive and gave me assistance all the time. He still gives me help. The arrival of my grandchildren contributed enough to fill up my time.” (Participant 1)

"I’ve always been very positive. The support of colleagues helped me a lot.” (Participant 2)

"I had treatment for depression for one year. The biggest support was my daughter, although I received the concern of my husband and my parents. My daughter assumed the house and took care of everything.” (Participant 3)

"The greatest support is from my parents. From my colleagues there are some resentments because I am not working. I always waited for the protection of my father. He is always my support. My father is someone special. He does everything for me,enough to bother me. I am very grateful.” (Participant 4)

These positives reactions reported by the respondents can be explained because they were at a positive emotional state too. Olivier, Perez and Behr (2011: p. 1010), in a study that investigated workers dismissed by health problems, also noted the importance of family involvement in this process, since the family "plays an essential role in giving support and strength, thus the person may return to work more confident”. Other studies indicate that social support-especially at workplace-has a direct impact on reducing the level of stress and physical symptoms (Cropley \& Steptoe, 2005; Dolbier, Smith, \& Steinhardt, 2007; Thomas \& Borrayo, 2011; Lysaght, Fabrigar, Larmour-Trode, Stewart, \& Friesen, 2012).

\section{Final Considerations}

We sought to understand how absenteeism affects the individuals' lives. The literature on the subject has enabled us to understand the complexity of this process, since, for the worker who leaves his occupation, much of which was built until that date, including professional and personal plans are put to the test by the changes reconfiguring his life. Furthermore, as stated by Enriquez (1999: p. 69), “any job loss causes a deep wound on the identity of different people, contributing to the breakdown of their personalities".

The results from the interviews showed that participants' feelings of estrangement, fear, emptiness, depression, helplessness and dependence are part of the reality of who is disconnected from his labor activity, indicating great uncertainty generated by this situation. This situation can also lead to social devaluation and consequent identity crisis, since work is a source of recognition of the others and ourselves. People faced with the reality of rupture and/or withdraw from workplace, may initially lead themselves to a significant loss of the sense of existence, by not knowing which way to go and what to plan for the future. Work is the object of which people appropriated entirely until now, and it cannot be disconnected from other experiences. Work provides the meaning for people and fosters them to a better life as a whole (Pratt \& Ashforth, 2003; Morin, Tonelli, \& Pliopas, 2007; Vilas Boas \& Morin, 2013a, 2013b).

The contact with colleagues and the work environment are stimulating and become part of the subject's life. Thus, work is not restricted solely to profit and income. This implies that human beings establish relations through work and in these relationships are included routine, fixed time, people, their activity and recognition. We also emphasize that family is an important support. It functions as foundation, refuge and greeting for the unconformity of having to return home. When the family is present and offer support, the individual may feel the sense of finitude, helplessness and disability minimized. Many individuals rely only on the family, perhaps the comfort of closeness and fear and insecurity of the outside world, i.e., comments and social prejudice. Social 
support from family and friends helps to ensure that workers increase their ability to manage the job requirements and their stress level (Cropley \& Steptoe, 2005; Dolbier, Smith, \& Steinhardt, 2007; Thomas \& Borrayo, 2011; Lysaght et al., 2012). Thus, these interpersonal factors that allow social support should be considered in the programs/interventions that aim to (re)integrate subjects into the world of work or programs intended to prepare workers for absenteeism or retirement itself (Dolbier, Smith, \& Steinhardt, 2007; Hepburn, Franche, \& Francis, 2010).

Human being craves for recognition and recognition improves quality of working life (Vilas Boas \& Morin, 2014). This characteristic is something remarkable in all of us, and its absence may hamper the planning and formulation of innovative ideas for changing some activities and/or continuing an active life within the conditions that our health allows. The process of absenteeism is painful for many, although they cannot express what they feel. What we can see is that people tend to get used or settled down with the condition. Within the time they lost their values, aspirations, and desires. Everything is seen as stable. They say they're fine the way they are. Their worldviews shrink and cannot observe the field of opportunities to explore other skills. By accepting their conditions, many fall ill, become depressed and are become increasingly susceptible to emotional problems. They need an activity to replace the occupation they have always had, but end up losing this perspective.

As pointed out by Costa and Soares (2009), it is possible to see that even after retirement, we still find many individuals who continue working toward a higher income, as well as others that even with guaranteed income, they cannot distance themselves from their work activities after encountering the need for better mental health. Within this perspective, the psychologist has paramount importance in being with these people, promoting mental health, making these individuals go through these processes of change in a structured manner and prospects. This way, they can find other activities and reborn for other experiences and occupations. The role of psychologist becomes necessary to steer these individuals and show them their appreciation and alternatives, as well as new life projects to be built (Costa \& Soares, 2009).

It should be remembered that a limitation of our study was the small number of interviewees-which does not allow a broad generalization of the results presented here. In-depth interviews used in this study lose in generalization, however, gain robustness to deepen the experiences reported by workers out of work, thus allowing us to understand the psychosocial factors involved in this complex process of absenteeism. It would be important to group more data (in this perspective of in-depth comprehension of experiences) by interviewing new employees out of work. As an experience generally painful, many subjects are not available to relive this painful process through participating in a survey. Another suggestion for future studies would be to do a review of data taking into account gender, age and ethnicity of people out of work. Some studies have indicated that men and womenby gender, age, ethnicity-respond in a different way to the experiences and challenges of work, stressful situations, positive and negative effects of work, social support, removal/return to work, and retirement (Cropley \& Steptoe, 2005; Franche, Baril, Shaw, Nicholas, \& Loisel, 2005; Franche, Cullen, Clarke, Irvin, Sinclair, \& Frank, 2005; Shaw et al., 2008; Tompa et al., 2008; Hepburn, Franche, \& Francis, 2010; McNamara, Brown, Aumann, Pitt-Catsouphes, Galinsky, \& Bond, 2013).

\section{Conclusion}

Taking into consideration the psychosocial impacts of psychosocial factors (social support, affect, coping skills and perception of future and health status) involved in absenteeism and the process of withdrawing work/ absenteeism - and its consequences on people's lives of this process, it is necessary to invest in more research that addresses this issue in order to build bridges between knowledge of organizational studies and organizational psychology. The issues discussed here are important because they reflect the fears, needs and feelings of individuals who are already in a situation of absenteeism. Nevertheless, they are also extremely important in the relationship of the workers with their own activities and their perspectives beyond that status.

\section{Acknowledgements}

We thank Lavras University Center (UNILAVRAS) and Research Support Program of Federal Technology University of Paraná-Campus Francisco Beltrão (DIRPPG/UTFPR-FB) for supporting the research.

\section{References}

Antunes, R. (1999). Os sentidos do trabalho. Ensaios sobre a afirmação e a negação do trabalho. São Paulo: Boitempo. 
Araújo, R. R., \& Sachuk, M. I. (2007). Os sentidos do trabalho e suas implicações na formação dos indivíduos inserido nas organizações contemporâneas. Revista de Gestão USP (REGE), 14, 53-66.

Bardin, L. (1995). Análise de conteúdo. Lisboa: Edições 70.

Bernal, A. O. (2010). Psicologia do Trabalho em um mundo globalizado: Como enfrentar o assédio psicológico e o estresse no trabalho. Porto Alegre: Artmed.

Costa, A. B., \& Soares, D. H. P. (2009). Orientação psicológica para a aposentadoria. Revista Psicologia: Organizações e Trabalho, 9, 97-108.

Cropley, M., \& Steptoe, A. (2005). Social Support, Life Events and Physical Symptoms: A Prospective Study of Chronic and Recent Life Stress in Men and Women. Psychology, Health \& Medicine, 10, 317-325. http://dx.doi.org/10.1080/1354850500093365

Devins, G. M., Bezjak, A., Mah, K., Loblaw, A., \& Gotoweic, A. (2006). Context Moderates Illness Induced Lifestyle Disruptions across Life Domains: A Test of the Illness Intrusiveness Theoretical Framework in Six Common Cancers. Psycho-Oncology, 15, 221-233. http://dx.doi.org/10.1002/pon.940

Dolbier, C., Smith, S., \& Steinhardt, M. (2007). Relationship of Protective Factors to Stress and Symptoms of Illness. American Journal of Health Behavior, 31, 423-433. http://dx.doi.org/10.5993/AJHB.31.4.9

Enriquez, E. (1999). Perda do trabalho, perda da identidade. In: M. R. Nabuco, \& A. Carvalho-Neto (Eds.), Relações de trabalho contemporâneas (pp. 69-83). Belo Horizonte: PUC Minas.

Franche, R.-L., Baril, R., Shaw, W., Nicholas, M., \& Loisel, P. (2005). Workplace-Based Return-to-Work Interventions: Optimizing the Role of Stakeholders in Implementation and Research. Journal of Occupational Rehabilitation, 15, 525-542. http://dx.doi.org/10.1007/s10926-005-8032-1

Franche, R.-L., Cullen, K., Clarke, J., Irvin, E., Sinclair, S., \& Frank, J. (2005). Workplace-Based Return-to-Work Interventions: A Systematic Review of the Quantitative Literature. Journal of Occupational Rehabilitation, 15, 607-631. http://dx.doi.org/10.1007/s10926-005-8038-8

Gerber, M., \& Puhse, U. (2008). “Don’t Crack under Pressure!” Do Leisure Time Physical Activity and Self-Esteem Moderate the Relationship between School-Based Stress and Psychosomatic Complaints? Journal of Psychosomatic Research, 65, 363-369. http://dx.doi.org/10.1016/j.jpsychores.2008.06.012

Hepburn, C. G., Franche, R.-L., \& Francis, L. (2010). Successful Return to Work: The Role of Fairness and WorkplaceBased Strategies. International Journal of Workplace Health Management, 3, 7-24. http://dx.doi.org/10.1108/17538351011031902

Jacques, M. G. C. (1997). Identidade e trabalho: Uma articulação indispensável. In: A. Tamayo, J. E. Borges-Andrade, \& W. Codo (Eds.), Trabalho, organizações e cultura (pp. 21-26). São Paulo: Cooperativa de Autores Associados.

Lacaz, F. A. C. (2009). Qualidade de vida n(d)o trabalho: Um conceito político e polissêmico. Trabalho, Educação e Saúde, 7, 565-572. http://dx.doi.org/10.1590/S1981-77462009000300010

Lukács, G. (1978). As bases ontológicas do pensamento e da atividade do homem. São Paulo: Livraria Editora Ciências Humanas Ltda.

Lysaght, R., Fabrigar, L., Larmour-Trode, S., Stewart, J., \& Friesen, M. (2012). Measuring Workplace Social Support for Workers with Disability. Journal of Occupational Rehabilitation, 22, 376-386. http://dx.doi.org/10.1007/s10926-012-9357-1

McNamara, T. K., Brown, M., Aumann, K., Pitt-Catsouphes, M., Galinsky, E., \& Bond, J. T. (2013). Working in Retirement-A Brief Report. Journal of Applied Gerontology, 32, 120-132. http://dx.doi.org/10.1177/0733464811408085

Mendes-Silva, M. A. S., \& Hashimoto, F. (2003). Afastados do trabalho: Repercussões na vida do indivíduo. Pulsional Revista de Psicanálise, 16, 32-37.

Minayo, M. C. S. (2004). O desafio do conhecimento: Pesquisa qualitative em saúde (8th ed.). São Paulo: Hucitec.

Morin, E. M. (2008). Sens du travail, santé mentale au travail et engagement organisationnel, Études et recherches (Rapport R-543-avec la collaboration de F. Aranha, FGV-EASP). Montreal, QC: IRSST.

Morin, E. M., Tonelli, M. J., \& Pliopas, A. L. V. (2007). O trabalho e seus sentidos. Psicologia \& Sociedade, 19, 47-56. http://dx.doi.org/10.1590/S0102-71822007000400008

Olivier, E. M., Perez, C. S., \& Behr, S. C. F. (2011). Trabalhadores afastados por transtornos mentais e de comportamento: O retorno aoambiente de trabalho e suas consequências na vida laboral e pessoal de alguns bancários. Revista de Administração Contemporânea, 15, 993-1015. http://dx.doi.org/10.1590/S1415-65552011000600003

Pratt, M. G., \& Ashforth, B. E. (2003). Fostering Meaningfulness in Working and at Work. In K. S. Cameron, J. E. Dutton, \& R. E. Quinn (Eds.), Positive Organizational Scholarship: Foundations of a New Discipline (pp. 309-327). San Francisco, CA: Berret-Koehler. 
Rodrigues, M., Ayabe, N. H., Lunardelli, M. C. F., \& Canêo, L. C. (2005). A preparação para a aposentadoria: O papel do psicólogo frente a essa questão. Revista Brasileira de Orientação Profissional, 6, 53-62.

Shaw, W., Hong, Q., Pransky, G., \& Loisel, P. (2008). A Literature Review Describing the Role of Return-to-Work Coordinators in Trial Programs and Interventions Designed to Prevent Workplace Disability. Journal of Occupational Rehabilitation, 18, 2-15. http://dx.doi.org/10.1007/s10926-007-9115-y

Soderstrom, M., Dolbier, C., Leiferman, J., \& Steinhardt, M. (2000). The Relationship of Hardiness, Coping Strategies, and Perceived Stress to Symptoms of Illness. Journal of Behavioral Medicine, 23, 311-328. http://dx.doi.org/10.1023/A:1005514310142

Thomas, J. J., \& Borrayo, E. A. (2011). An Examination of Moderators of Perceived Stress and Illness Behavior. Psychology, 2, 590-597. http://dx.doi.org/10.4236/psych.2011.26091

Tompa, E., Oliveira, C., Dolinschi, R., \& Irvin, E. (2008). A Systematic Review of Disability Management Interventions with Economic Evaluations. Journal of Occupational Rehabilitation, 18, 16-26. http://dx.doi.org/10.1007/s10926-007-9116-x

Vilas Boas, A. A., \& Morin, E. M. (2013a). Le Sens du Travail et la Qualité de Vie au Travail dans les Établissements Publics D’enseignement Supérieur: Une Comparaison entre le Brésil et le Canada. Proceedings of the Colloque International AFIRSE: Recherche en éducation: Continuité, rupture oulimites. Montréal: UQAM.

Vilas Boas, A. A., \& Morin, E. M. (2013b). Quality of Working Life in Public Higher Education Institutions: The Perception of Brazilian and Canadian Professors. International Journal of Business and Social Science (IJBSS), 4, 67-77.

Vilas Boas, A. A., \& Morin, E. M. (2014). Fatores de Qualidade de Vida no Trabalho em Universidades Públicas: Uma Comparação entre Brasil e Canadá. Proceedings of the 14th Congress of Stress of ISMA-BR (International Stress Management Association) and 16th Forum of Quality of Working Life. Porto Alegre.

Wrzesniewski, A., Dutton, J. E., \& Debebe, G. (2003). Interpersonal Sensemaking and the Meaning of Work. Research in Organizational Behavior, 25, 93-135. http://dx.doi.org/10.1016/S0191-3085(03)25003-6 